\title{
Professor Pietro (Pier) Alberto Bertazzi (1945-2021)
}

\author{
Angela Cecilia Pesatori (i) 1,2 Dario Consonni (1) ${ }^{2}$
}

We are deeply saddened by the passing of Professor Pietro (Pier) Alberto Bertazzi, MD, MPH, who died on 15 September 2021.

Pier (as he was called) graduated in medicine in 1971. His early interest in epidemiology is testified by a thesis on epidemiological methods in occupational health as postgraduate student in occupational health in 1973. He was postdoctoral fellow at the department of epidemiology of the University of North Carolina in 1979-1980, then he was a visiting scientist at the National Institute for Occupational Safety and Health in 1980 . He attended epidemiology courses in Finland, the USA and at the International Agency for Research on Cancer (IARC).

Pier had a seminal role in fostering epidemiology in Italy by implementing the first occupational epidemiology unit at the Clinica del Lavoro 'Luigi Devoto', in Milan. In 1987, he organised courses with Harvey Checkoway and Neil Pearce (occupational epidemiology) and with David Kleimbaum (multivariable modelling) attended by dozens of students, many of whom later became epidemiologists in the most disparate fields. He was director of the department of occupational and environmental health in 2001-2005 and 2010-2015.

He made investigations on health effects due to exposure to lead, vinyl chloride, benzene, oil refinery products, polychlorobiphenyls, asbestos, tetrafluoroethylene and perfluoro-octanoate. Most were cohort studies, where collaboration with the industry was necessary. Nonetheless, he always kept firm his public role and ethical commitment to workers and their health, working with but not for the employers. He collaborated with IARC in multicentre

${ }^{1}$ Department of Clinical Sciences and Community Health, University of Milan, Milan, Italy

'Epidemiology Unit, Fondazione IRCCS Ca' Granda Ospedale Maggiore Policlinico, Milan, Italy

Correspondence to Dr Angela Cecilia Pesatori, Department of Clinical Sciences and Community Health, University of Milan, Milan 20122, Italy; angela.pesatori@unimi.it cohort projects on herbicides, chlorophenols and dioxins and man-made vitreous fibres, and was a member of six working groups of the IARC Monographs on the Evaluation of the Carcinogenic Risks to Humans. Pier's name is indeed mostly linked to the landmark study on mortality and cancer incidence in the Seveso area. Investigating cancer incidence in a place where no cancer registry existed was a formidable challenge, but Pier strongly believed in that project and managed to build a unique population-based cohort study in which tens of thousands of clinical records had to be collected by hand in many hospital archives.

Pier's peculiar trait has always been his open-mindedness and his ability to acknowledge new opportunities and new research fields. In the early 2000s, he established a laboratory of molecular biology applied to occupational and environmental risks in the context of the Environment and Genetics in Lung Cancer Aetiology study, funded by the National Cancer Institute (USA). Later on, Pier strongly supported the launch of an epigenetics laboratory, one of the first in Italy dedicated to occupational and environmental hazards. Although with a clever vision of the future, he was aware of the importance of the past: one of his important contributions was the digitalisation of old issues of the journal La Medicina del Lavoro, the first occupational medicine journal.

Pier had always a profound sense of the importance of working with people: he was an enthusiastic supporter of the creation of an international community of occupational epidemiologists. That community convened in 1981 in the first International Symposium on Epidemiology in Occupational Health and finally led to the birth of the Scientific Committee on Epidemiology in Occupational Health (EPICOH) of the International Commission on Occupational Health (ICOH). $\mathrm{He}$ organised two EPICOH symposiums in Como (1985 and 1994), was EPICOH secretary in 1993-1996 and president in

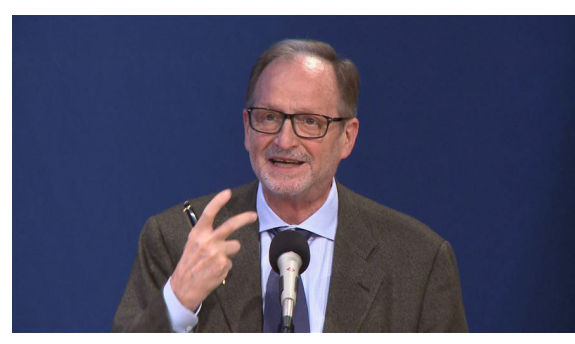

1996-2000. His contribution to ICOH was valuable and long-lasting as he was ICOH board member in 2000-2003, scientific chairman of the Centennial Congress of ICOH 2006 and was nominated ICOH honorary member in 2009 for his contribution to the promotion of occupational health.

Pier was a calm and deeply thoughtful person. He did not act as a leader; he was a natural leader. He used to say, if the purpose is clear, difficulties are not an objection'. Indeed, working with him, we learnt to face problems and look at them as opportunities for a new and deeper knowledge. He appreciated each of his collaborators' distinct talent and inspired everyone to put their interests and skills to work.

There still would be much to say, so we stop here. We only wish a last warm greeting to a great scientist, a great person, and a dear mentor and friend.

Contributors The authors equally contributed to the drafting and revision of the submitted obituary.

Funding The authors have not declared a specific grant for this research from any funding agency in the public, commercial or not-for-profit sectors.

Competing interests None declared.

Patient consent for publication Not applicable.

Provenance and peer review Not commissioned; internally peer reviewed.

(c) Author(s) (or their employer(s)) 2022. No commercial re-use. See rights and permissions. Published by BMJ.

D Check for updates

To cite Pesatori AC, Consonni D. Occup Environ Med 2022;79:72

Published Online First 29 October 2021

Occup Environ Med 2022;79:72.

doi:10.1136/oemed-2021-108032

\section{ORCID iDs}

Angela Cecilia Pesatori http://orcid.org/0000-00020261-3252

Dario Consonni http://orcid.org/0000-0002-8935-3843 